\title{
The Use of Persuasive Language in Christian Fundraising: Coercion or Motivation?
}

\author{
Juliet Oppong-Asare Ansah, ${ }^{1}$ (D) Osei Yaw Akoto², (iD) Richard Ansah' ${ }^{3}$ (D) \\ 1 Department of Language and Communication Sciences, Kwame Nkrumah University of Science and Technology, Kumasi, Ghana. \\ 2 Department of English, Kwame Nkrumah University of Science and Technology, Kumasi, Ghana. \\ 3 Department of Classics and Philosophy, University of Cape Coast, Cape Coast, Ghana.
}

\begin{abstract}
This paper is an expose on how fundraisers in some churches in Ghana use persuasive language, also referred to as 'loaded words' on their congregation to stir up their emotions to adhere to their demands and succumb to their instructions and directions. It specifically recounts persuasive expressions or utterances used by personalities who solicit funds from the congregation during fundraising ceremonies and discusses the effectiveness of these expressions. It also presents the perception and reaction of church members on how their thoughts, feelings or behavior are influenced by the astute words of fundraisers. Using a qualitative research approach, five recorded audios are selected, transcribed and codified for textual analysis. Sections of the churches visited were engaged in interactions to inquire about their perception of these modes of fundraising. The findings indicated that most fundraisers who solicit funds for the churches in question are imported, thus, they perform the assigned task to meet the churches' needs and to also boost their remuneration. It also indicated, based on church members interviewed, that the strategies they use in fundraising, to some extent, are effective tools to sway the congregation to give their monies out when they are still faced with personal challenges. This paper contributes to research knowledge on some less explored areas such as persuasion in the context of fundraising in the Christian mission.
\end{abstract}

Keywords: Fundraising, Christianity, Persuasion, Appeal, Motivation

Correspondence

Juliet Oppong-Asare Ansah

Email: juvenro@gmail.com

Publication History

Received 30th October 2020,

Accepted 24th November 2020,

Published online 14th December

2020.

(C) 2020 The Authors. Published and Maintained by Noyam Publishers.

This is an open access article under the CCBY license (http://creativecommons.org/licenses/by/4.0/).

\section{INTRODUCTION}

Churches all over the world, in one way or the other, rely on their members for the upkeep of the church as an institution and as a facility. Members of good standing in the society are made to support church activities with their substance with the use of "loaded words." The question as to whether these persuasive words stimulate the members to act beyond their planned intention to function at a point in time remains unrequited. This paper provides an indepth content analysis of audios from fundraising sessions in selected churches. It further identifies and discusses the noticeable persuasive strategies used during these sessions. It finally enquires from church members on how the use of persuasion influences their giving during fundraising in the church.

\section{PERSUASION}

Scholars have defined persuasion from different perspectives. ${ }^{2}$ This paper dwells on the communicative definition which considers persuasion as a process in which a communicator seeks to elicit a desired response from his receiver. ${ }^{3}$ In persuasion, there is always a conscious attempt to change the ideology, beliefs and attitude of others by voluntarily

\footnotetext{
Kendra Cherry, Psychological Persuasion Techniques: Persuasion Techniques That Really Work. Social Psychology Newsletter. (2019):3.

2 Richard M. Perloff, The Dynamics Of Persuasion: Communication And Attitudes In The $21^{\text {st }}$ Century, $2^{\text {nd }}$ Ed. (New Jersey: Lawrence Erlbaum Associates. 2003):7.

3 Allan Andersen, African reformation: African initiated Christianity in the 20th century. (Trenton Africa: Word Press. 2001):6.
} 
accepting a new cognitive pattern of overt behavior ${ }^{4}$ of one's audience without considering their emotional, physical or economic state of the persuaded. Persuaders adopt swaying strategies to highlight crucial points or to present ideas that, in the end, enable them to obtain their arguments to convince their listeners ${ }^{5}$. The core function of persuasion is "to capture an audience, sway the undecided and convert the opposition". ${ }^{6}$ In reality, only a few people are naturally endowed with eloquence and charisma to convince other people; thus, persuasion requires specific expertise and constant preparation for its purpose to be achieved.

Persuasion, as a strategy that influences people to act beyond the typical state, is guided by three basic pillars or rhetorical appeals, around which all strategies and techniques revolve. ${ }^{7}$ These are logos, ethos and pathos. Logos is the ability of the persuader to create a logical argument that appeals. People appeal to logic by using facts, figures, case studies, data and numbers. Besides these variables, the persuaders also take keen note of their reputation and trustworthiness to prove the authenticity of the information they are giving by maintaining internal consistency and clarity within the argument. Therefore; they use stylistic features like tones and posture to attract the attention of their listeners. Ethos also involves the standing character or the fundamental principles of the persuader. These include their position, achievement, track record and authority concerning the subject of discussion. Persuaders are, in most cases, experts and beneficiaries of what is being "imposed" on others and they exhibit some sort of evidence that self-explains why people should come on board. The last pillar, pathos, is the ability to appeal to the audience's feelings and passion with a call to emotions (both positive and negative). Speakers use impassionate plea or convincing stories to create an emotional or imaginative impact on the listeners. Fundraisers using pathos create scenarios or refer to sensitive events that ignite the softest feelings of the listeners to adhere to their beckoning.

\section{Cialdini Principles on Persuasion}

A line can be drawn between the above pillars underpinning the concept of persuasion and the principles guiding it. Cialdini provides six principles that, if not all, should be evident in persuasion. ${ }^{8}$ Three of them are briefly discussed in this paper. The first principle, without following a particular order, is reciprocity. This principle states that a persuasive message must contain a message that implies that whatever substance people put into anything will return to their favor. In its application, Christian fundraisers usually quote scriptures from the Bible which give the assurance that the reward in whatever they give to God or charity will be much more than what they give as seen in the scripture below:

"Give, and you will receive. Your gift will return to you in full - pressed down, shaken together to make room for more, running over, and poured into your lap. The amount you give will determine the amount you get back." Luke 6:38 (NLT).

Another dimension of the principle of reciprocity is that givers also take into consideration how well fundraisers utilize what they take. An instance was witnessed in one of the conversations recorded for this paper. A middle-aged woman

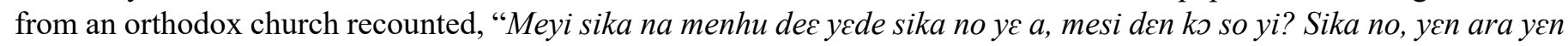

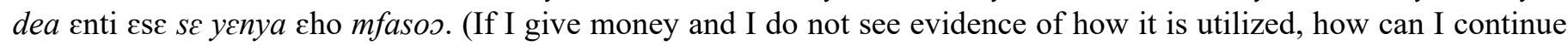
to give? The money is ours so we should benefit from it)." This was a response to a question of why some people are hesitant to give an offering. There is an obvious fact that Christians believe that whatever they give at Church is indirectly given to God, yet the human eye seeks to see an indication of its usage.

The second principle is scarcity; a principle which holds the view that people want more of what they have less of. In its application, persuasive messages highlight unique benefits and exclusive information that assure proposed givers of "filling their cup" which actually is empty or half-filled. People in the Church lack one thing or the other; there is the sick who seek good health, the jobless, the childless, the unmarried, etc. These challenges, therefore, become fertile grounds for fundraisers to sway them. For instance, a fundraiser may say, "I challenge anyone who is believing God for a financial breakthrough to sow a seed and see what the Lord will do". This is a practice in Christianity where people give sacrificially in response to a course such as prophecy, preaching, or worship. A person who is going through financial crises will succumb to this declaration because he has the quest to shedding off the scarcity.

The third principle of persuasion is authority. This principle holds the notion that people defer to experts. In other words, people who are endowed with specific expertise advantageously apply it to persuade others. This principle is applied in business outreaches when people who have adopted a particular business strategy and have sailed through mount the podium to tell their story to convert new entrants. As they speak, they also apply the principle of authority by exposing their expertise. Cialdini, therefore, advises persuaders not to assume that their expertise is self-evident. ${ }^{9}$

\footnotetext{
Daniel J. O'Keefe, Persuasion: Theory and research (3rd edition). (Newbury Park, CA: Sage. 2015):26.

Martin Adam, Persuasion In Religious Discourse: Enhancing Credibility In Sermon Titles And Openings, Discourse and Interaction 10 no. 2, (2017): 2-25.

Robert B. Cialdini, Harnessing The Science Of Persuasion. (New York: Harvard Business Review, 2001): 70-80.

John C. Ramage, John C. Bean \& June Johnson. Writing Argument: A Rhetoric With Readings (11 ${ }^{\text {th }}$ edition). (USA: Pearson Learning Centre, 2019): 62-63.

Cialdini, Harnessing The Science Of Persuasion, 70-80.

Cialdini, Harnessing The Science Of Persuasion, 70-80.
} 
A cross-section of the audience may have foreknowledge of the success story of the fundraiser, there are however others who need to be told to make a decision. In the church, people are known to be good fundraisers and each is identified with a particular strategy that is appropriate for specific forms of fundraising.

\section{Giving in the Christian Context}

Christianity can be practiced or expressed within the cultural context of the group of people identified as Christians; people who are noted to be followers of Jesus Christ, the founder of the Christian religion. ${ }^{10}$ The major goal of Christianity is to profess the faith, vision, mission, activities, challenges, etc. of what they stand for. From the doctrinal point of view, Goh affirms that Christianity has a strong agenda to reach out to and influence non-believers through an outreach program variously referred to as "evangelism", "proselytizing" "conversion", "witnessing," and many more. ${ }^{11}$ This outreach mandate is imperative, yet, Goh opines that this "Great Commission" does not receive the same emphasis among all Christians. ${ }^{12}$ Since the introduction of Christianity in the Gold Coast, precisely Elmina, by the Portuguese in 1482, the successive years witnessed a dribble of various European protestant missionaries ${ }^{13}$ which differ marginally or considerably in faith, doctrine, or practice. Christians engage in many activities which include giving. Giving in the Christian setting takes many forms that are discussed later in the paper.

\section{Purpose of fundraising in the church}

The church as an institution needs money to function and in this regard, it is identified with varied forms of fundraising. ${ }^{14}$ The ultimate aim of this exercise is to mobilize funds to run the affairs of the church. Reid outlines six avenues where church funds, specifically tithes, are channeled into. ${ }^{15}$ To him, the first purpose of the funds is to keep the ministry in a position where they can focus on work, that is, these monies put the church in a position to pay wages and other incentives like lodging and transportation to church workers including ministers. Secondly, these funds are used to maintain the church premises by way of gardening, repairs, etc. The third purpose of church funds is to use it to support needy church members. He explains further that, some churches use "secondary" funds to perform this task or supplement the portion of the main fund allotted to charity. The fourth purpose of church funds is to support mission work, both internally and externally. Fifthly, financially independent churches, in some cases, use part of their funds to support "less financially viable" churches. These are satellite churches planted by the well-established ones. Lastly, the church uses part of its funds to support local charities by investing in schools, hospitals, etc. The above purposes manifest in the ideal situations of the church. However, to Taylor, these religious purposes are impossible to define because what constitutes them is within the discretion of either church officials or the congregation. ${ }^{16}$ This remains an issue of controversy in churches today.

Many people in the church criticize leadership for their extensive collection of monies without using them for their core purpose. In an unpublished manuscript, Reid highlights certain keys to explain that the church has deviated from its biblical financial mandate ${ }^{17}$. To quote him, "... the pastor pressures people to give more..., many churches launch a "stewardship" campaign, where members are asked to pledge how much they will give in the coming year". ${ }^{18}$ Citing Paul's instructions through his letter to Timothy, it urges Christians to devote themselves to taking care of their home first before considering the church. Again, they should not spend impulsively but follow an orderly plan. In other words, the church must raise monies through the "generous grace of giving" of its members. It is obvious that some members of the church are endowed with so many financial blessings. These persons can, in so many ways, assist the church in its financial endeavors so taking from the congregation should not be a general exercise.

"Instruct those who are rich in this present world not to be conceited or to fix their hope on the uncertainty of riches, but on God, who richly supplies us with all things to enjoy. Instruct them to do good, to be rich in good works, to be generous and ready to share, storing up for themselves the treasure of a good foundation for the future, so that they may take hold of that which is life indeed" (1 Timothy 5:8 NASB).

Regarding the mode of collecting money from church members, Cole goes on to advise the church not to raise

\footnotetext{
10 Joel Mokhoathi. From The Contextual Theology To African Christianity: The Consideration Of Adiaphora From A South African Perspective. Religions 8 no. 266, (2017): 1-14.

11 Robbie B.H. Goh, Christianity, Transnationalism and Indian Identities: The Problematic Role of Religion in Singapore, Journal Religion and Society 13, (2011): 1-20.

12 Goh, Christianity, transnationalism and Indian identities, 1-4.

13 David K. Amponsah. Christian slavery, colonialism and violence: The life and writings an African ex-slave, 1717-1747. Journal of Africana Religions 1 no. 4, (2013): 431-457.

14 Steven J. Cole, The Church And Money - Various Scriptures. (Unpublished Scriptural Teaching -Lesson 15 2017)

15 Joel Reid. What Should Tithe Money Be Used For In The Church? (2017).accessed on 10 ${ }^{\text {th }}$ October, 2019. https:/www.quora.com/What-should-tithe-money-be-used-for-in-the-church

16 Barry W. Taylor, Diversion Of Church Funds To Personal Use: State, Federal And Private Sanctions, Journal of Criminal Law and Criminology 73 no. 3 , (1982): 1204-1237.

17 Reid, What Should Tithe Money Be Used For In The Church?

18 Reid, What Should Tithe Money Be Used For In The Church?
} 
money through annual pledge drives, through promoting tithing, or through any worldly, high-pressured methods. ${ }^{19}$

Ahiabor and Mensah are also of the view that the church as a religious organization should always remember their status as a non-profit organization and so should rather be concerned with the welfare of its members. ${ }^{20}$ Hence, the direction of funds should rather be from the church to the congregation.

\section{Sources of Church Funds}

Church funds are mobilized from different sources. The most common and easiest means is for the church to receive money from church members. ${ }^{21}$ Besides this, the church can engage in investment ventures in the form of businesses including selling church souvenirs like stickers, wristbands, etc. Some churches also have cafeterias and shops which members patronize for the benefit of the entire church. Some churches also have state of the art edifices (auditorium, conference halls, event grounds, etc.) which other churches and individuals hire for a fee. All these are avenues the church relies on for funding. Church members tend to be the basic financiers and they are regularly reminded of this responsibility. ${ }^{22}$ They pay different forms of monies to the church, of which some are mandatory while others are optional. Optional monies include offering, seed sowing, thanksgiving offering, etc. Payment of mandatories monies such as welfare dues, departmental dues and, in some churches, tithes depend on the structure and policies of the church in question. These include the amount to be paid and the time to pay them. They are clearly specified and enforced by the by-laws of the church. Some of the monies paid in churches are discussed below.

\section{Church offering}

The word 'offering' originated from the Latin word oferre 'bestow'. Below are some definitions from renowned dictionaries and they would be used as a point of departure. An offering is something offered, especially, a sacrifice, ceremonially offered as part of worship or "a contribution to the support of the church. ${ }^{23}$ The second definition considers an offering as money people give in their church during a Christian service. ${ }^{24}$ The third dictionary definition of offering is "a gift that people give to their God or gods as a form of worship. ${ }^{25}$ Fourthly, an offering is something that is given to God or something that is given as a present to please someone. ${ }^{26}$ Lastly, an offering is defined as something sacrificial. ${ }^{27}$ Inferring from the above dictionary definitions, there is a fact that an offering is a substance (tangible gift) that is offered sacrificially; thus one should not be obliged to give. Secondly, an offering is a ceremonial religious practice that is performed only when there is a service. Additionally, an offering is given to show one's reverence to a higher being (which, in the case of the Christian, God). Lastly, an offering can be in any form of substance, including money. The Old Testament provides diverse forms of offering in the bible with specific instructions and patterns attached to them. For instance, the scripture below talks about the burnt offering Cain and Abel offered to God.

Genesis 4:3-4: In the course of time Cain brought some fruits of the soil as an offering to the Lord. And Abel also brought an offering- fat portion from some the firstborn of his flock. The Lord looked in favor on Abel and his offering (NIV).

The offerings given by Cain and Abel were freewill or sacrificial offerings; although there was a principle guiding their giving (that is, sacrificing the best) they were given the chance to choose the kind of substance to sacrifice willingly. Contrary to this, there are instances in the Old Testament where God specifically instructed people to offer something to Him. For instance, in the scripture below, God told Moses to take the atonement money from the children of Israel. In this command, God was specific about the reason for the offering (sin atonement), the form it must take (money), what the offering should be used for (maintenance of the temple) and the benefit of the offering to those who give (serving as a memorial for them).

Exodus 30:16: Receive the atonement money from the Israelites and use it for the service of the tent of meeting.

It will be a memorial for the Israelites before the Lord, making atonement for your lives (NIV).

Church offering in contemporary churches takes different forms and it is dependent on the structures of the church. They sometimes go by different names, yet they have the same reference. These offerings include to mention a few, tithe,

\footnotetext{
19 Cole, The Church And Money - Various Scriptures.

20 Godson Ahiabor \& Collins C. Y Mensah. Effectiveness Of Internal Control On The Finances Of Churches In Greater Accra, Ghana, Research Journal of Finance and Accounting 4 no.13, (2013):115-121.

21 Robert Ntibalema \& Agnes Mugaya. Sources Of Church Finance In The Church Today: Reliability And Sustainability. (Germany: Lambert Academic Publishing 2012):7.

22 Helen J. Irvine, Balancing Money And Mission In A Local Church Budget, Accounting, Auditing and Accountability Journal 18, no. 2 , (2005): 211 -237.

23 Merriam-Webster collegiate dictionary (10 ${ }^{\text {th }}$ Edition). (Merriam-Webster Incorporated. 1999).

24 Macmillan English dictionary for advanced learners. (McMillan Education. 2007).

25 Collins COBUILD advanced English dictionary. (Glasgow: HarperCollins Publishers. 2003).

26 Longman dictionary of contemporary English ( $6^{\text {th }}$ edition). (Harlow, England: Pearson Education. 2014).

27 The Cambridge advanced learners dictionary (4th ${ }^{\text {th }}$ edition). (ISBN: 9781107035157. 2013).
} 
day-born offering (Kofi and Ama) ${ }^{28}$, welfare offerings ${ }^{29}$, seed offerings, special program offerings such as those taken during pastors' appreciation, revivals, annual harvest and Departmental day celebration (men's day, women's day, youth day, children's day, etc.).

\section{Tithe}

Tithe, in its basic description, is a tenth part of one's income paid voluntarily or obligatorily, depending on the structures and statutes of the church. Its ultimate purpose is to support the clergy or the church. Payment of tithe is one controversial issue in many Christian denominations in Ghana. Questions regarding the time to pay tithe and whether to pay on one's gross or net income have still not been duly answered. Probably, to clear this clamor, there is a need to consider the kind of work the tithe payer does. For instance, a businessman whose profit is realized on daily basis may decide to pay the tithe weekly while the monthly salary worker pays it at the end of the month.

Again, the mode of collecting tithe varies from church to church. For instance, two members from two different orthodox churches (Roman Catholic and Methodist Church respectively) affirmed that their churches provide envelopes through their day-born groups which they anonymously put their money in and submit on the first Sundays of every month. Similarly, a member of the Church of Pentecost explained that members pay their tithes without the church disclosing the amount they pay. However, in the Assemblies of God Church, as indicated by a member, records of tithes paid by members are documented and archived. An elder of this church was probed and his justification was that, first, it has to be recorded so that the church will know the commitment of members. In his own words, he explained

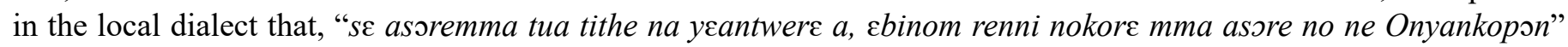
(if members pay tithe and we do not record, some may not be loyal or faithful to God and the church). The second justification was that the act of recording tithes paid puts checks on the church workers as well. ${ }^{30} \mathrm{He}$ lamented, "nnipa

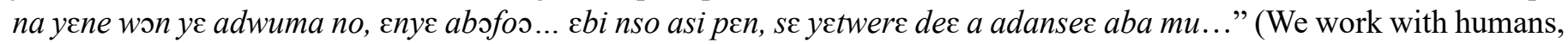
not angels ... .besides, it has happened before, if it is recorded, there will be evidence of payment). He gave another reason that, when tithes of church members are recorded, it allows the church to know when members are progressing or retrogressing financially so they can offer assistance to those who are in need. In conclusion, he mentioned that, since the church expects every working adult to pay tithe, the amount paid is determined by the payer and the consequences are determined by God.

\section{Church Dues}

This is money members pay for the management of the church. It is one of the main means of funding in the church. In some local churches, a stipulated amount of money is paid monthly through a channel. For instance, a member of the Assemblies of God International Church at Airport Roundabout disclosed that every member is expected to pay an amount of five cedis every month and this is recorded. The informant stressed that reminders are given to members every week as part of the church's announcement. Payment of dues is voluntary, yet, one's refusal to pay might bring certain consequences. For instance, an elder from a Methodist Church the authors interacted with on $3^{\text {rd }}$ August 2019 at Atonsu Bokuro in Kumasi said this in Akan:

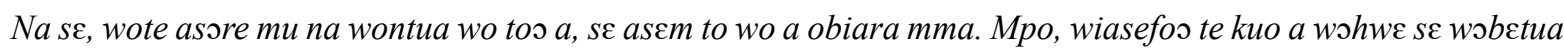

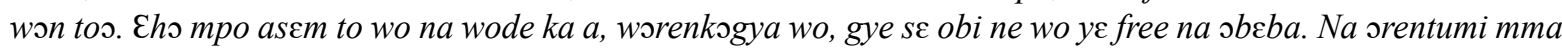
wo asore no din mu.

"But if you a member of a church and you refuse to pay your dues, if calamity befalls you, no one will come and support you. Even in the secular world, association members are required to pay their dues. Even there, if calamity befalls you and you are owing, they will not come to support you, only individuals who are in your clique will come and support you. Even that, they cannot come as representatives of the church."

The above statement obviously implies that dues payment in that church determines an individual's membership. It is deduced that dues are used to take care of members' welfare but further interaction with him revealed that the dues paid are for the upkeep of the church and that there is a special dues allotted for members' wellbeing. An interviewee in Kentinkrono (a suburb of Kumasi) who worships with another orthodox church explained in an Akan-English codeswitch as follows:

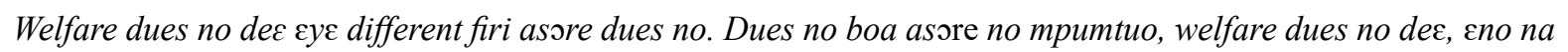
yede supporte asoremma no. Nsore pii nso ye saa. Asore a cto so four a mako ni. Ne nyinaa mu no yegye dues ne

\footnotetext{
${ }_{28}$ Kofi is a name given to a male born on Friday among the Akan and other non-Akan speakers in Ghana while Ama is a name for a female born on Saturday. Depending on the ethnic group, these names are written with slight variation. For instance, while the Akuapim and Asante dialect speaker call the Friday born male Kofi, Fanti speakers call them Fiifi.

29 Welfare offering is a special offering taken by the church to take care of their social responsibilities such as supporting bereaved persons, those in need, marriages, etc.

${ }^{30}$ These are members that the church assigns to receive and record tithes.
} 
welfare bosome biara two Ghana anaa five Ghana.

"Welfare dues are different from church dues. The church dues help in the development of the church. As for the welfare dues, it is used to cater for the needs of the church members. Many churches do the same thing. This is the fourth church I have joined (as a member) and in all, church dues and welfare dues of two cedis or five cedis are paid every month."

Sometimes, church dues and welfare dues are decentralized at the day-born or societal levels where a member pays through the leadership at the decentralized units which serve as the first point of contact to or mediator between the dues payer and the church, thereby receiving and recording the money on behalf of the church. For instance, in the Catholic Church, members pay monthly dues through societies like the Christian Mothers' Association, St. Theresa of the Child Jesus, Charismatic Renewal Society, Legion of Mary and the day-born societies (Kofi ne Ama) one belongs to. The day-born groups are also used for other purposes as far as fundraising is concerned. In many churches in Ghana, day born offering is taken on scheduled times of the month. Whiles some take it on the first Sundays, others also take it on the last Sundays. Some churches also use this means to collect tithe. The Assemblies of God International Church at Airport Roundabout-Buokrom in Kumasi uses this medium to take their welfare offering.

\section{Management of church funds}

The church as an organization is expected to assign its fund management to an internal control body that will control or manage the finances of the church. However, as indicated by Ahiabor and Mensah, church leaders or religious organizations hesitate to implement sound control policies because of the fear of appearing untrusting. ${ }^{31}$ These authors' assertion concurs with Laughlin's argument that most churches are of the view that accounting, as an activity, should not interfere with the churches' spiritual endeavour which is of more importance. ${ }^{32}$ In contrast, Irvine holds an opposing view that religious organizations can co-exist with accounting systems and even embrace it as a valuable tool in the fulfilment of its spiritual mission. ${ }^{33}$ If the two variables are well married and managed, there will be smooth running of the affairs of the church. This is not an impossible mission, yet accountability in the churches seems like a nightmare. This occurs as a result of many factors, one of which is the observation of Taylor that, religious organizations are vulnerable (although less vulnerable than secular organizations) to fiscal abuse because neither the church members nor the government closely monitors their financial affairs. ${ }^{34}$

\section{METHODOLOGY}

Data for this paper was mainly acquired through audio recordings from fundraising sessions of three Pentecostal churches, specifically, The Assemblies of God denomination. Prior to this research, fundraising services of different denominations in Ghana such as The Methodist Church, The Roman Catholic Church, The Church of Pentecost and The Assemblies of God had been observed by the researchers. Differences in the mode of fundraising in the respective churches were obvious. It was seen that Methodist and Roman Catholic churches had regulated methods of fundraising which every fundraiser was obliged to follow. Although they used persons who seemed proficient in the field, they worked within the stipulated structures. Additionally, the frequency of fundraising was limited in the two denominations. The above observations contrasted with that of the Church of Pentecost and Assemblies of God. Since these latter churches had certain similarities, Assemblies of God churches were chosen because there were further interesting observations that fit within the focus of the paper; they had many fundraising sessions within the year, they, in most cases, relied on guest fundraisers who used diverse persuasive strategies. Recordings were done within June 2019 and January 2020 in four churches in Kumasi and three in Cape Coast (both are cities in Ghana). ${ }^{35}$ These two places were chosen per the location or institutional affiliations of the authors. This made recordings in the two locations easier and convenient. Fundraising sessions during which recordings took place, included services like pastor's appreciations, revivals (fasting and prayers), acquisition of church equipment, end of year thanksgiving and societal day celebrations. Some of the services were conducted in English while others were in the local dialect. There were instances where fundraisers used code-mixing or their messages were interpreted. An average of 240 minutes recordings comprising 28 audio recordings were compiled. Five were selected randomly and transcribed into text after which the selected audios were codified. ${ }^{36}$ The respective fundraisers were given pseudo names. Table 1 below summarizes the five selected audios for discussion.

\footnotetext{
31 Godson Ahiabor, \& Collins C. Y Mensah. Effectiveness of internal control on the finances of churches in Greater Accra, Ghana. (Research Journal of Finance and Accounting 4 no. 13 2013): 115-121.

32 Richard C. Laughlin. Accounting in its social context: an analysis of the accounting systems of the Church of England. (Accounting Auditing and Accountability Journal, 1 no. 2, 19-42): 1988.

33 Helen J. Irvine. Balancing money and mission in a local church budget. (Accounting, Auditing and Accountability Journal 18 no. $2,211-237$ ): 2005.

34 Taylor. Diversion of church funds to personal use: state, federal and private sanctions.

35 There were multiple recordings in the selected churches in different times.

36 Codes were coined from the initials of "Persuasive Fund Raising" (PFR) followed by a chronological number.
} 
Table 1: Selected Audios for Discussion

\begin{tabular}{|l|l|l|l|}
\hline Code & Date/time & Purpose & Duration \\
\hline PFR1 & $6^{\text {th }}$ October, 2019 / 10:26GMT & To purchasing of chairs for service & $06 \mathrm{mins}, 44 \mathrm{secs}$ \\
\hline PFR2 & $27^{\text {th }}$ January, 2020 / 20:18GMT & 21-days fasting and prayers & $03 \mathrm{mins}, 02 \mathrm{secs}$ \\
\hline PFR3 & $1^{\text {st }}$ December, 2019 $/ 12: 52 \mathrm{GMT}$ & End of year harvest fundraising & $34 \mathrm{mins}, 52 \mathrm{secs}$ \\
\hline PFR4 & $13^{\text {th }}$ October, 2019 $/ 13: 26 \mathrm{GMT}$ & Pastor's Appreciation & $14 \mathrm{mins}, 47 \mathrm{secs}$ \\
\hline PFR5 & $19^{\text {th }}$ January, 2020 $/ 12: 35 \mathrm{GMT}$ & Towards church building renovation & $10 \mathrm{mins}, 04 \mathrm{secs}$ \\
\hline
\end{tabular}

Interviewees that were involved in the current research were randomly selected. During the visits to the churches (both before the research and during the data collection period), some members were interrogated concerning their views on monies their respective churches take from them and what motivated them to give. Other people outside the church were also interrogated and responses retrieved from them were not different because most of them had an affiliation with a church and few ones who, at that time, did not attend church were once members of a particular church. Few ones claimed have changed denominations for reasons that are not discussed in this paper. In all, one hundred and thirteen (113) people, comprising fifty-nine (59) males and fifty-four (54) females, were interviewed. Out of the total number, fifty-three (53) belong to the Assemblies of God church, thirty-one (31) from the Church of Pentecost, fourteen (14) from the Methodist Church while fifteen (15) were from the Roman Catholic Church. These numbers were arrived at by chance since the interviewees were randomly chosen. There were no structured questions, however, every question sought to know the forms, purposes and modes of collection of church funds as well as the members' reaction to the modes.

\section{FINDINGS AND DISCUSSION}

The discussion of the transcribed audios reveals that Christian fundraisers adopt quite a number of persuasive strategies or variables in their quest to sway the respective congregation to succumb to their demands. Aside from the use of variables including literary devices (puns, repetitions, rhetorical questions, touches of sarcasm, similes, imagery, metaphors, tones and exaggeration), the fundraisers use major strategies like the appeal strategy. All these are combined in a way to help the fundraisers achieve their aim. In the subsequent section of this paper, the researchers provide a content analysis of transcribed audios and highlight the respective strategies adopted to raise funds for specific purposes.

\section{Persuasive Fund Raising (PFR) Audio 1}

This audio was recorded during a fundraising session at a Charismatic church in Cape Coast (Assemblies of God Students' Ministry AGCM-UCC Chapter). The purpose of the fundraising was to get additional plastic chairs to meet the demands of the expanding congregation. The fundraiser, NB, ${ }^{37}$ was a guest pastor invited probably, for this course. Being an experienced pastor and holding an office at the church's district leadership, NB seemed to speak with authority. He began his fundraising with the expression, "Accra Hearts of Oak ${ }^{38}$ T-shirt, twenty thousand Ghana (GH $\not 20,000)$ ". This expression sounds more exaggerating because the amount quoted was outrageous and too good to believe. Initially, two interpretations came to mind. First, there was a possibility that this amount was paid for the T-shirt during its launch because in such programs monies given do not represent the true value of items in question. The second possible interpretation was that the fundraiser might have misquoted the amount he meant because this has been a common mistake most Ghanaians make since Ghana's currency was changed from "cedi" to "Ghana cedi". However, his constant repetition of the statement and further comparison with foreign teams like Real Madrid and Manchester United made his claim obvious and purposeful. The religiosity among Christians is evident in, among other things, setting their priorities. Christians are urged to place a premium on the things of God rather than 'things of the world'. The fundraiser's comment seemed incomplete, yet it implied that if one could buy a T-shirt of a football team for such an amount, then much more should be given to help God's work. Fundraisers usually base their argument on the biblical scripture in Matthew 6:33 39 to ascertain the need to consider things of God before any other thing.

The next strategy N.B. used was taking the first step in giving towards the purchase of chairs for the ministry. With this personal appeal "...Papa, I just took fifty cedis from my car to help this church. And I want people to challenge my God", he shows his reputation for honesty in terms of giving towards God's work. Personalizing the phrase "...my God" is an indication of this kind of appeal. This gesture is strategic in the sense that most fundraisers only position themselves on the side that suits their role; thus, they take from the congregation without giving as well. His action, in a way, motivated a cross-section of the congregation to give. Again, pioneering the donation with his fifty cedis serves

\footnotetext{
37 This and all the other fundraisers are given pseudo names.

38 Accra Hearts of Oak is one of the premier football clubs in Ghana, and like many other teams, they have replica jerseys supporters buy as a way of patronage and or showing their loyalty.

39 Seek first the kingdom of God and His righteousness, and all these things will be added unto you (ESV)
} 
as an indicator of the highest amount he is likely to call for.

The second part of the sentence was a challenge to give. One key belief Christians hold on to is that God rewards givers ${ }^{40}$ as seen in bible scriptures like Acts $20: 35^{41}$ and Luke 8:38. ${ }^{42}$ Fundraisers use this principle as a bait to get givers into a tight corner. NB, in his next statement, said, "in my church, I do not beg people to come and give to God, I always tell them they must beg God to give to them". Here, he covertly convinces the people that they do not lose by giving, rather it becomes an avenue for them to attract God's blessings for themselves. ${ }^{43}$ With the expressions like "start giving big currencies on weekdays", "Do not wait till Sundays, during Bible Studies to give fifty Ghana cedis", "You think God only comes on Sundays so you give coins", he urges them further that they should not just give, but they should always give bountifully. In the end, people gave according to their financial strength towards the various amounts called for in the order of fifty, twenty, ten, five and any amount one could give.

\title{
Persuasive Fund Raising (PFR) Audio 2
}

The next audio under consideration was recorded on $27^{\text {th }}$ January, 2020 at the Assemblies of God International Church in Kumasi during a 21-days fasting and prayer programme. This is a usual practice in many churches today. They organize a fast and pray at the beginning of the year to prepare themselves for the times ahead (as explained by one of the congregants). They erect huge banners and posters to create awareness for reasons best known to them. The fundraiser, DOI was a guest speaker invited to lead the program during the second week and every night after the ministration he raised funds for the church, a practice he called, giving the people the chance to draw blessings from God. Unlike the first fundraiser, DOI is a leader and founder ${ }^{44}$ of a church in Kumasi with few branches within the city's environs. He is not fluent in the English language so he delivered most of his messages in Asante Twi, a dialect of Akan and when necessary, an interpreter translated his message into English. In his ten minutes fundraising session, he used several appeals to draw money from the people. He began with the following message:

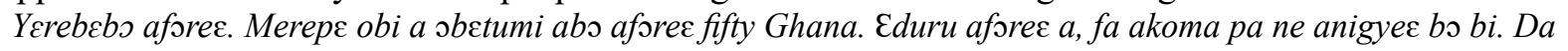
biara, meka kyere m'asore se, "mfa sika no nkots indomie.

"We are going to give an offering. I want someone to give an offering of fifty Ghana cedis. When it is time for offering, give with a good heart and joy. I always tell my church that they should not spend their monies on indomie (a kind of noodle)."

Announcing his intention to raise funds is like calling the people to order or preparing their minds to the task. Thus preparing their mind and heart emotionally towards giving. The emotional appeal continues as the fundraiser tries to draw the congregation's mind to the fact that it is one thing giving and another thing giving from your heart. This might have been informed by what the bible says in 2Corinthians 2:7.45 This is a common scripture most fundraisers quote to make givers feel they are not been forced to give. Like NB's style, DOI also made a comparison between giving money to God and using it to buy food. Here, he draws givers' attention to the fact that they should invest their monies in the work of God rather than on food that perishes. He again assured them of the benefit of giving - blessing from

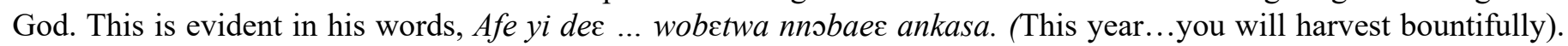
This assurance, obviously, will convince the average Christian, especially coming from a person known as a powerful prophet of God as he constantly reminded them of his calling as a prophet. Intermittently he will say, bo nne date to ho... se meyc Onyame diifos a wobshunu nscnkyercne "Write today's date down... if I am a prophet of God, you will get a miracle". He then made the following submissions:

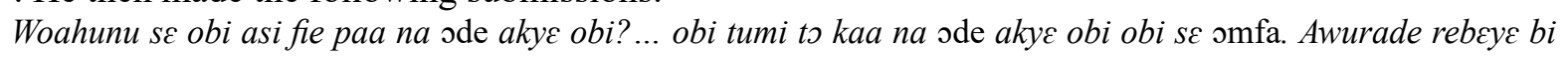

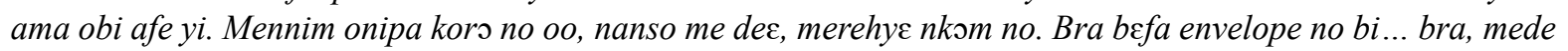

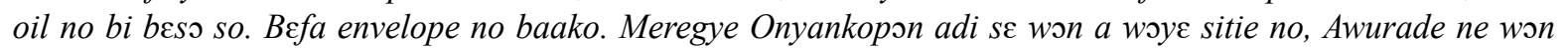
bebo три пе три.

\begin{abstract}
"Have you seen someone giving a house he has built to someone as a gift before? ... Someone buys a car and gives it to another person as a gift. God is going to do that for someone this year. I do not know that person but I am prophesying. Come and pick one of the envelopes... come, I will sprinkle oil on it. Come for one of the envelopes. I am trusting God to have an encounter with those who will be obedient to Him."
\end{abstract}

In the above statement, he buttressed his point with a scenario to create a mental picture of the blessings that await intended givers. He further shared a personal experience he had with a gentleman in his church who gave some money

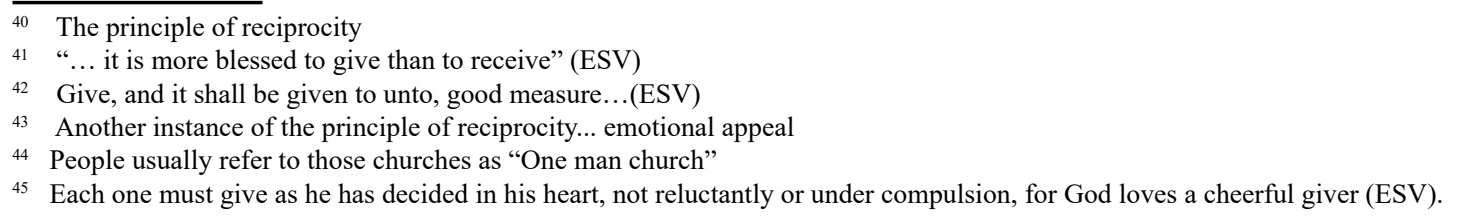


he never planned to give during a service. He recounted how he needed money for an impending program and he prophesied to this gentleman that someone is about to bless him with money. Then the gentleman said, Papa, mete nka wo me mu se memfa sika no nkye wo "Papa, I feel it within my spirit that I should give the money to you". He, with this story, urged the congregants to follow their instinct and give to test God and see if He will not cause people to help them to travel and give them capital for their businesses. All these stories are emotional appeals that draw people's affection for giving. The issue of sprinkling oil on the envelopes is another strategy Christian fundraisers use. Olive oil (usually referred to as 'anointing oil') has become one of the major religious monuments in Christianity today. A lot of testimonies are given in churches, social media and electronic media about how 'anointing oil' has caused breakthroughs in people's life. Some neo-Pentecostal pastors ${ }^{46}$ brand their oils and have different oils for specific issues. Therefore, for the envelopes to be 'anointed', they are perceived to be authenticated and that the possibility for those who give to be blessed is assured. This fundraising, like the first one, ended with people giving according to how they have been convinced or their financial strength. They gave fifty cedis, twenty cedis, ten cedis, five cedis and any amount they could give ${ }^{47}$.

\title{
Persuasive Fund Raising (PFR) Audio 3
}

This audio was recorded on $1^{\text {st }}$ December, 2019 in another Charismatic church in Kumasi during the churches' endof-year harvest. The fundraiser, RQ, happened to be a regular guest speaker; he had been invited to the church several times and as he said in his introductory speech, Obiaa nim se meyc efie nnipa, menye hohos "Everyone knows me as part of you. I am not a stranger". He is a pastor and the founder of a church he manages in Kumasi. The thirty-four minutes audio contains a number of appeals which sought to inspire the congregants' motive and affect their attitudes towards giving. The fundraiser is fluent in both English language and the local dialect so he code-mixed the two languages during the service. He used a much longer time for the fundraising because it was a Sunday joint service and also it was a harvest in which the main focus was 'giving of money'. His open statement was quite humorous.

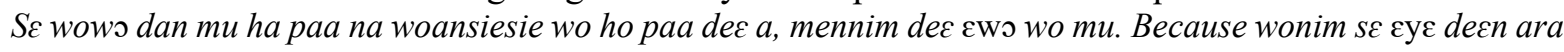
a wei, yebrye. Oh, Okristoni ben na owo ha a onnim? Nkramofoo koraa nim se Akristofo bo aforee afe awieec...

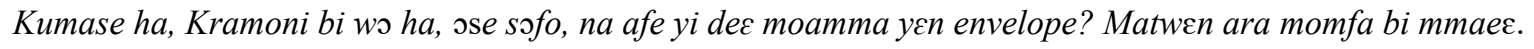

"If you are in this room unprepared, then I do not know what you are made of. Because you know we will definitely do this. Is there a Christian who is not aware of this? Moslems are even aware that Christians organize annual harvests at the end of the year. There is a Moslem in Kumasi who asked, 'Pastor, won't you give us envelopes ${ }^{48}$ this year? I have expected it but you haven't brought them."

With this statement, he reminds the church of having no excuse to default in their giving because they were expected to have foreknowledge of the harvest, and the fact that a Moslem, whose religion opposes that of the Christian in terms of doctrine, belief and practice, has opted to give to the church, is a challenge to those gathered who are stakeholders of the church to give. With this appeal, the fundraiser stirs up the emotion of the congregants, thereby motivating them to give.

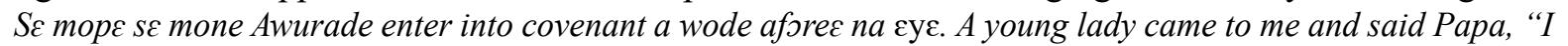
want to buy one of the garments you will wear on your apostolic ordination". Ena obisaa me se, "what is the price

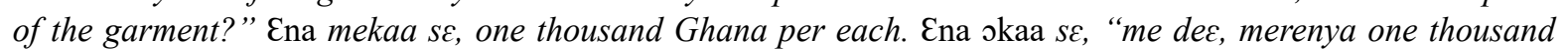
Ghana but I will give you two hundred Ghana". So the girl sowed a seed. Osow seed no wiees no, there was a young man a na wahu no se sbeware no... I told the lady to bring the two hundred Ghana and when the lady brought the money, I prayed for her...

\begin{abstract}
"If you want to enter into covenant with God you do that with giving of an offering. A young lady came to me and said Papa, "I want to buy one of the garments you will wear on your apostolic ordination and she asked me for the price of the garment. I told her one cost a thousand Ghana cedis. She then said, she could not afford the total cost and so she did sow a seed. After sowing the seed, there was a gentleman who had seen the lady and promised to marry her... I told the lady to bring the two hundred Ghana cedis, she said she could afford it and I prayed for her."
\end{abstract}

Here, the fundraiser employed rational appeal by taking into consideration the people's practical, functional and utilitarian need and emphasizing the need and the benefit of owning it. The story ended that after the lady sowed the seed, a gentleman came and gave the lady keys to his house in Accra, ${ }^{49}$ gave her permission to use his car in the house

\footnotetext{
46 Those pastors who "own one man" churches.

47 What we sarcastically call the free-zone giving

48 Most Christians, during their annual harvests give envelopes to people, irrespective of religion or denomination, to contribute to their course. These envelopes (and sometimes tally cards) are given prior to the harvest. They usually inscribe some basic information at the back which include their name and location, date of the harvest, purpose of the harvest, a column for the giver's name and amount donated.

49 Accra is the capital city of Ghana.
} 
and also bought a shop for the lady and gave her capital to start selling cosmetics. There are, obviously, many spinsters in the church who seek marriage and a story of this nature is likely to stimulate them to give so that their needs would be met. The fundraiser extended this stylistic appeal to telling a biblical story of Hanna. He said in the following words;

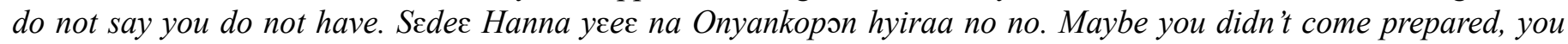
can pledge. I know you are honorable people and you always redeem your pledges. "Do not say you have no money. Just as Hanna did for God to bless her..." All these rational appeals, in the end, may stir up the emotions of those who find themselves in similar situations and the effect might either be positive or negative. ${ }^{50} \mathrm{He}$ called the first amount which is ten thousand Ghana cedis and at this point, nobody had come forward. However, as indicated by De Haven, ${ }^{51}$ "persuasion does not automatically leave an impression on a donor" therefore it is to the advantage of the fundraiser to determine how to move a step further to know the appropriate persuasion principle to employ at a particular time. At this point, the fundraiser by these words, "I know things are hard in this season but this is a covenant offering you are giving to God," convinced them not to consider their current financial standing but give all they have and also see it as a covenant they are entering with God, a relationship every Christian wishes to have with God. He then quoted the amounts in a range - from ten thousand to five thousand and yet no one had moved. He then repeated his words as follows:

If you can give five thousand to ten thousand and enter a covenant with God come. It can be ten thousand, five thousand, seven thousand, eight thousand, whatever. Come and let me pray for you and God will surprise you. Is there anybody here who is ready for the blessing? Do not look up to anybody. Just come forward for your blessing.

At this point, a question was asked "Do the persuasive words of the fundraiser matter?" Few people responded this time but because the amounts were within a range, one could not tell the amount each donor was there to give or pledge. Their giving was followed by a command to stand in front for a prayer; oil was poured into their palm and they were asked to rub it and pour their heart desire unto God. The words in the fundraiser's prayer were also convincing and assuring in a way as seen below:

From today, may God enter into a covenant of wealth with you; I am trusting God for it. May it happen to you in Jesus' name; may you never lack; the hand of God will see you through in Jesus' mighty name.

The fundraiser seemed disappointed at this time and so his words became somehow stronger and as he uttered the words below one could see on the faces of the people that they were pressed. ${ }^{52}$

Mmara da Onyankopsn assrefie. Obiara nni ho a yerebo aforee a sbetumi aka se onni sika. Se woyare na yese yenksto mogya a anka yebrnya sika ats. The Bible says nobody should come into the presence of God empty handed.

“There is law in the house of God. None of you present can say he doesn't have money during harvest. If you are sick and need blood transfusion you would have gotten money for it. The Bible says nobody should come into the presence of God empty handed."

Logically, one may feel threatened frightened that their health is not paramount. However, in the setting they found themselves in, faith superseded reasoning. Again, likening 'giving' to the law of God has the potential to put the individual in a state of fear since no Christian wishes to violate it. The stillness of the room, at this point, made the place unfriendly and this supports the assertion that fear appeal can influence the behavior and emotion of the donor negatively. Yet the fundraiser, noticing this situation, presented a humorous utterance thereafter and it created some laughter in the auditorium. He said,

So efiri nne reks decide on the amount you want to put aside every month. Pع susu box na fa sie. That money should be untouchable, se worewu mpo a mfa wo nsa nka. Da a wobswu no tell them, mewo sika bi hys ha, da a

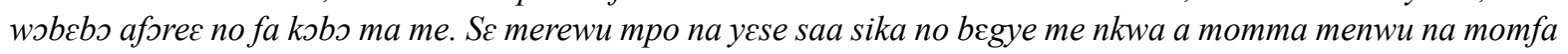
nksbo aforę mma me. Na Onyame behyira wo.

"So from today decide on the amount you want to put aside every month. Get a susu box ${ }^{53}$ for safe keeping. That money should be untouchable, even in death, do not touch it. The day you die, inform them you have an amount of money hidden somewhere, they should send it to the church for you on the day of harvest. If I am dying and they say this money can safe my life, allow me to die and use the money as offering on my behalf and God will bless vou."

\footnotetext{
50 Viktorija Grigaliunaite \& Lina Pileliene, Emotional Or Rational? The Determination Of The Influence Of Advertising Appeal On Advertising Effectiveness, Scientific Annals of Economics and Business, 63 no.3, (2016):391-414.

51 Brett de Hevan,. Principles Of Persuasion For Non-Profit Fundraisers. (M.A Thesis submitted to the Graduate Faculty of the University of Akron. 2010).

52 This is a clear evidence of fear appeal.

53 Susu is an informal form of saving where people personally put some monies aside without spending them. People usually put the money in small boxes made
} by carpenters. There is a kind of drift of the traditional wood box since we now have some made of paper and plastic. 
The above message can only be treated as humour because this would not happen in real life. The Akan adage abaa nna ho mma skraman nka nnipa "One does not leave the stick untouched and allow the dog to bite a human being" connotes that no one will choose to die and keep money that could have saved him or her for harvest. Again how will God bless someone who has died already? In the end, people responded by picking envelopes and pledged to pay later.

\section{Persuasive Fund Raising (PFR) Audio 4}

This video was recorded on $13^{\text {th }}$ October, 2019 in another Assemblies of God in Buokrom, Kumasi. The purpose of the fundraising was to show appreciation to the senior pastor of the church. This is an annual norm but the date varies every year. The fundraiser, KB, is a pastor of an Accra branch of the same church the fundraising took place in. His church is a big - huge edifice, has a large congregation, sophisticated infrastructure and committed congregation as well. He proudly gave all this information before the service. He is fluent in both English and Asante Twi, yet he used English frequently. He began his fundraising with the following message:

"Today we are here to honor a man of God... When you are convinced, please come forward... Just two people. If I have not seen it, I won't say it. I want you to challenge my God. If you give out this money, something unusual is going to happen within the next six months."

One thing about this fundraiser which was different from the earlier ones is that he called people to come forward without first mentioning the expected amount. At this point, there is a possibility that the congregants were contemplating whether they should go forward or not. Prior to the fundraising, he had mentioned huge amounts his church members willingly give to support his church. Hence the expected amount, in this case, would perceivably be high. After pausing for some seconds, he continued by saying he wanted just two people to come forward. Why two people? Will it not place a burden on them? Yet, the follow-up comment confirmed he really meant 'two'. "If I have not seen it, I won't say it." Once again the prophetic declaration had been made and it seemed it is the language that often jolts Christians, especially, in the area of giving. To strengthen the prophecy, the fundraiser used the expression "I want you to challenge my God," as has been heard from earlier fundraisers. It, then, became more convincing when the 'reward' that awaits whoever takes the bold step ${ }^{54}$ to come forward was declared; "If you give out this money, something unusual is going to happen within the next six months." The above utterances appeared to be a fear appeal in the sense that one's refusal to respond could be seen as disobedience or 'blowing off' one's blessing. However, the expected amount had not been spelt out.

KB continued with a logical appeal when he said, "you are giving it to the servant of God. Somebody God has a covenant with." Fundraisers DOI and RQ stressed the fact that giving in the house of God serves as a covenant between God and the giver. In this text, the fundraiser clarified that this money was not being given to the church but to the pastor. Thus, how does one enter into a covenant with God when the money is given to the pastor? To assure the giver of this covenant, the fundraiser drew attention to the fact that the man in question was someone God had a covenant with, and logically, whoever gives to him becomes a partaker of this covenant - simple logic. This assertion was backed by his next quote "...and the bible says that anyone who offers a prophet a glass of water, He will honor that person." At

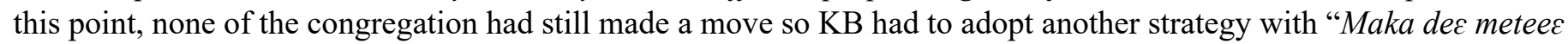
akyere wo, but if you still want to be a Nicodemos, after the service you can come and see me." "I have told you what I heard but if you want to be discreet, after the service you can come and see me". It seemed, here, that the fundraiser, among other things, thought the people might have the desire to come but found it difficult to come up front so he gave them the option of seeing him after the service. This strategy still seemed not to sway the congregation, even with the repetition of "come, and you will never regret giving this offering." He then came up with a contradictory statement, "we are honoring God. This is also a form of worship. We do not worship God by singing and dancing alone. Our offering is also a form of worship to God. A few minutes earlier we were honoring man, now we are honoring God. The answer to any "why question" can only be salvaged from the horse's own mouth." It is obvious that fundraisers become confused sometimes as this case showed.

When finally he mentioned the amount, there was a moment of relief in the auditorium. In his words, how many of you can honor your pastor with two thousand? If you want me to walk to you, I will come..., Seven people then slowly got up, one after the other, towards the pulpit. Then the question people seemed to ask might be, "Did the pastor see well?" He then said, I said two people and after a long pause continued, "I saw two people but people can sometimes forcibly attach themselves into some blessings." On seeing the confusion on the faces of some of the congregants, he applied a cliché by quoting Matthew $11: 12^{55}$ and referred to the story in Genesis Chapter 27 where Jacob stole his brother, Esau's blessing from their father. He stressed that a person can outrun other persons and take a blessing not meant for them. He prayed for the people and received their monies which were already in envelopes. The amount

\footnotetext{
54 Usually referred to as, "yielding to the beckon of the Holy Spirit" by some church fundraisers.

55 From the days of John the Baptist until now, the kingdom of heaven suffers violence and the violent take it by force.
} 
dwindled to one thousand, seven hundred and five hundred, which he thought everyone present should be able to give.

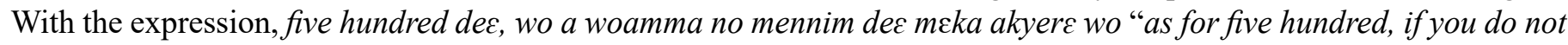
come forward I wouldn't know what to tell you". It was obvious that in his church, this amount is among the least that people give on such occasions. In the end, dee wows biara fa bra "you can bring any amount you have" was announced and surprisingly, a lot of people moved forward and it was possible people gave more than the highest amount called; this was evident in comments people made in the interaction the researchers had with them which is discussed later in this paper.

\section{Persuasive Fund Raising (PFR) Audio 5}

This audio was recorded on $19^{\text {th }}$ January, 2020 in Assemblies of God International Church in Kumasi. This church usually has two services on Sundays; the first is an English Service and the second is a combination of English and Akan (the dialect depends on the preacher invited to the day's service). The fundraiser, PPOA, was the only female fundraiser captured for this paper. The purpose of this fundraising was to raise money to augment the church's budget for the renovation of their auditorium. She is a leader of an outreach ministry that focuses on village evangelism. Her fundraising was done within ten minutes and four seconds. She used two main persuasive strategies in her fundraising. First, she used anecdotes - the use of short (personal) stories to illustrate points and second, she used clichés - quoting biblical scriptures. All these were done before calling people to come forward. Her fundraising was the most straight forward one among all the audios recorded. She enlisted items needed for the renovation of the church building such as paints, cement, sand, louvre blades, etc. and quoted the unit price for each item. She then gave the instruction, Nnezma no mu dodos biara a wobetumi ats no, bra anim na beka gu m'asom. Yebetwere wo din na wo were firi a yeakae wo.

"Among the listed item, any quantity you can secure for the church, come and whisper to me. We will write your name so that if you forget we will remind you."

One thing that came to bear about this fundraising was that the people felt comfortable and gave freely. It appeared that almost everyone in the church gave an amount.

From all the audios discussed, the researchers now state their findings on the subject. It was discovered that a common feature runs through all the five audio recordings that have been discussed. Although they do not follow any strict order, but they are seen in almost all the audios. These are:

1. The Announcement stage where fundraisers mention the stage they have reached in the day's service.

2. Declaration of purpose - here, fundraisers declare the main purpose of the fundraising. For example, to honor a man of God, to purchase chairs for a church, etc.

3. Psyching the congregation - fundraisers prepare the mind of the people concerning the task ahead.

4. The battleground - this is where the 'tag of war' between fundraisers and donors ensue. It is a game of attacks and resistance where the former seek to drip the former of a treasure they also try to cling to.

5. The soothing stage where fundraisers assure donors of replenishment of their loss.

\section{Highlights of Respondents' Concerns}

As stated earlier, 113 respondents were interrogated and among other subjects discussed, they expressed their views on the mode of fundraising in their churches. Excerpts of the concerns expressed are outlined below. ${ }^{56}$ Their identities are concealed and codified.

1. "I love those challenges. I know myself, I am not easily convinced, especially when it comes to giving. Sometimes I have the desire to give but something presses me to stop. When they use all these words like; Onyankopsn behyira wo "God will bless you", and share people's experiences, I am moved to do likewise. I believe there is blessing in giving."

2. "Sometimes I know I have plans for the money but when I am challenged to give, I do. But when the plan I have for the money is serious and immediate, I pledge and bring the money later. I believe God blesses those who give but we also need to work hard."

3. "It becomes embarrassing when they call people to give, especially when they mention those amounts I do not have. People might think I am stingy because they judge by how we look but the truth is, I may not have that amount. I do not like taking risks. What if I go forward and make a promise and things get bad and I am not able to pay? Because of this, if I know the program involves money and I do not have, I do not come to church at all. I believe there is blessing in giving but I do not give under compulsion. If I give and I have regrets within me, then my blessing is not automatic."

\footnotetext{
56 The excerpt constitute the actual words of the people. They are not altered. However, those uttered in the local language are translated into English.
} 
4. "Sometimes I have the money but I refuse to go forward. In our society when people see you give huge monies in public they conclude that you are rich and they always come to you for help. So I wait until they call people to bring whatever they have so people are unable to predict what I give. God knows the heart of man and our enthusiasm to give, so if I give in public or not He will bless me."

5. "The Bible says we should give discreetly so when I give openly, to me, I am showing off so I usually do not go and when the "show" is over, I give whatever I have directly to the pastor. I do not remember receiving anything in particular after giving money at church but I know God's blessings take different forms. Even the gift of life is a blessing so He blessed me."

6. "Any time I am going to church and I know there will be fundraising of a sort, I think of the amount I can afford to give and I put it in an envelope. So no amount of convincing words will change my mind. God has blessed me so many times but I do not think it is because I gave."

From the above excerpts, it can be deduced that most of the church members do not have problems with the money they give to the church, even those who do not have a strong financial stance desire to contribute their widow's mite during fundraising. However, when fundraisers persuade them consistently to give, it ceases to be mere motivation to give towards church development. They see it as rather being coerced. This mode, in reality, discourages the members to give instead of encouraging them. The negative impact of pressed modes of fundraising such as; patronizing those who are unable to give much, exposing those who give huge amounts of money in church to people who may take advantage of these donors, people regretting after impulse spending, to mention a few, causes the members to reconsider their decision regarding church attendance when fundraising is announced, as indicated by some of the respondents. This, in the end, places the Church at a loss because obstinate members maintain their stance and refuse to succumb to the loaded words of the fundraiser.

\section{RECOMMENDATION}

After an in-depth discussion of five selected videos regarding Christian fundraising and the concerns a cross-section of members of the churches provided, the authors make two vital recommendations The main focus of the interaction was to know their views on the way fundraisers persuade them to give during church programs and the influence the persuasion have on them. Firstly, people in Christian settings should not be swayed to give. The church should devote itself to teaching biblical principles of personal financial management. With this, the person will be exposed to their financial obligation in the church and attend to it voluntarily without being forced. One issue that came up in this investigation is that, when fundraisers are invited from other churches, the host church pays them for their services, and as such, they are obliged to raise funds so that they do not over-burden their host. Again, they are somehow influenced by the culture in their local churches and thereby apply them in the churches they are invited to. In this light, the second recommendation is that churches should rely on their own people during fundraising because they are always with them and they are likely to understand the people and also will work within their culture. This will, in the end, put both the fundraiser and the donor on the same favourable page.

\section{CONCLUSION}

More often than not, fundraisers make certain decisions on how to carve their messages in order to reach their target audience and this, they do with the help of persuasive strategies such as personal appeals - using their personality or charisma to sway congregation, emotional appeal - using fear, prophesies, loves, desires, dreams to manipulate the emotions of the congregation, logical or rational appeal - drawing their attention to reality through sharing of testimonies and stylistic appeal - the use of stories, evidence, symbolism, etc. Interaction with some members of the churches where data was gathered reveals that these strategies have both positive and negative impact on the congregation. Again, the motive of fundraisers to sway the people is not always achieved in the sense that emotions, are "complex critters which involves a cognitive assessment of a situation, psychological arousal, a subjective sets of feelings, motivation to behave in a certain way..." ${ }^{57}$ yet this cannot always be predicted and influenced. There is therefore a need for fundraisers to keep to the tune of donors for giving to be done freely and without cohesion.

\footnotetext{
57 Robin. L. Nabi. Emotion and media effects. (In R. L. Nabi \& M. B. Oliver (Eds.), The Sage handbook of media processes and effects. Thousand Oaks, CA: Sage. 2009): 205-221.
} 


\section{ABOUT AUTHORS}

Juliet Oppong-Asare Ansah is a Lecturer in the Department of Language and Communication Sciences, Faculty of Social Sciences, College of Humanities and Social Sciences, Kwame Nkrumah University of Science and Technology, Ghana. She holds Bachelor of Education in Psychology and Master of Philosophy in Ghanaian Language (both from the University of Cape Coast, Ghana). Currently, she is a $\mathrm{PhD}$ candidate in Linguistics at the University of Ghana, Accra-Ghana. She teaches Semantics, Aesthetics of Oral Literature, Translation, Creative Writing, Pragmatics and Akan Written Expression. Her research is focused on Ethnographic Linguistics, Diachronic Studies, Semantics and its interfaces, Language Contact and Translation Studies.

Osei Yaw Akoto (PhD) is a Lecturer in the Department of English, Faculty of Social Sciences, College of Humanities and Social Sciences, Kwame Nkrumah University of Science and Technology, Ghana. He holds a BA(Hons) in English Language and Philosophy; MPhil and PhD in English Language, all from the University of Cape Coast, Ghana. He teaches English for Academic Purposes, Sociolinguistics, Discourse Studies and Error Analysis. His research is focused on Linguistic Landscape, Onomastics, Corpus Linguistics and Academic Discourse.

Reverend Richard Ansah (PhD) is a Senior Lecturer in the Department of Classics and Philosophy, Faculty of Arts, College of Humanities and Legal Studies, University of Cape Coast, Ghana. He hold a BA (Hons) in Philosophy and History, M.Phil. in Philosophy, both in the University of Cape Coast, Ghana and PhD in Philosophy from the University of South Africa, Pretoria, South Africa. He also holds a Diploma in Theology from the Assemblies of God Theological Seminary, Saltpond, Ghana. His research is focused on Logic, Critical Thinking, Philosophy of Language and Philosophy of mind.

\section{BIBLIOGRAPHY}

Adam, Martin. Persuasion in Religious Discourse: Enhancing Credibility in Sermon Titles and Openings.Discourse and Interaction 10, no. 2, (2017): 2-25. https://doi.org/10.5817/di2017-2-5

Ahiabor, Godson \& Mensah, Collins C. Y. Effectiveness of Internal Control on the Finances of Churches in Greater Accra, Ghana. Research Journal of Finance and Accounting 4, no.13, (2013): 115-121.

Amponsah, David. K. Christian Slavery, Colonialism and Violence: The Life and Writings on African Ex-slave, 1717-1747. Journal of Africana Religions 1, no.4, (2013): 431-457. https://doi.org/10.5325/jafrireli.1.4.0431

Andersen, Allan. African Reformation: African Initiated Christianity in the 20th Century. New Jersey: Word Press. 2001.

Cambridge Advanced Learners Dictionary (4th Edition). ISBN: 9781107035157. 2013.

Cherry, Kendra. Psychological Persuasion Techniques: Persuasion Techniques that Really Work. Social Psychology. (2019):1-13.

Cialdini, Robert. B. Harnessing the Science of Persuasion. Harvard Business Review (2001): 70-80.

Cole, Steven J. The Church and Money (Various Scriptures). Unpublished Scriptural Teaching (Lesson 15). 2017

Collins COBUILD Advanced English Dictionary. (Glasgow: HarperCollins Publishers. 2003).

De Hevan, Brett. Principles of Persuasion for Non-profit Fundraisers. M.A Thesis Unpublished, Graduate Faculty of the University of Akron. 2010.

Goh, Robbie, B. H. Christianity, Transnationalism and Indian Identities: The Problematic Role of Religion in Singapore. Journal Religion and Society 13 (2011): 1-20.

Grigaliunaite, Viktorija. \& Pileliene, Lina. Emotional or Rational? The Determination of the Influence of Advertising Appeal on Advertising Effectiveness. Scientific Annals of Economics and Business 63, no. 3, (2016): 391-414. https://doi.org/10.1515/saeb-2016-0130

Irvine, Helen J. Balancing Money and Mission in a Local Church Budget. Accounting, Auditing and Accountability Journal 18, no. 2, (2005): 211-237. https://doi.org/10.1108/09513570510588733

Laughlin, Richard C. Accounting in Its Social Context: An Analysis of the Accounting Systems of the Church of England. Accounting Auditing and Accountability Journal 1, no 2 (1988): 19-42.

https://doi.org/10.1108/eum0000000004622

Longman Dictionary of Contemporary English ( $6^{\text {th }}$ Edition). (Harlow, England: Pearson Education. 2014).

Macmillan English Dictionary for Advanced Learners. (MacMillan Education, 2007).

Merriam-Webster Collegiate Dictionary (10 th Edition). Merriam-Webster Incorporated. 1999.

Mokhoathi, Joel. From the Contextual Theology to African Christianity: The Consideration of Adiaphora from a South African Perspective. Religions 8, no. 266 (2017): 1-14. https://doi.org/10.3390/rel8120266 
Nabi, Robin. L. Emotion and Media Effects. In The Sage Handbook of Media Processes and Effects, (205-221. (Thousand Oaks, CA: Sage, 2009).

Ntibalema, Robert. \& Mugaya, Agnes. Sources of church finance in the church today: reliability and sustainability. Germany: Lambert Academic Publishing, 2012).

O'Keefe, Daniel. J. Persuasion: Theory and Research (3 ${ }^{\text {rd }}$ Edition). (Newbury Park, CA: Sage, 2015).

Perloff, Richard. M. The Dynamics of Persuasion: Communication and Attitudes in the 21 st Century, $2^{\text {nd }}$ Edition. (New Jersey: Lawrence Erlbaum Associates, 2003).

Ramage, John. D., Bean, John. C. \& Johnson, June. Writing Argument: A Rhetoric with Readings, $11^{\text {th }}$ Edition). (USA: Pearson Learning Centre, 2019).

Reid, Joel. What Should Tithe Money be used for in the Church? Accessed October 10, 2019. https://www.quora.com/What-should-tithe-money-be-used-for-in-the-church

Tannenbaum, Melanie. B., Hepler, Justine., Zimmerman, Rick. S. Saul, Lindsey., Jacobs, Samantha., Wilson, Kristina. \& Albarracin, Dolores. Appealing to Fear: A Meta-Analysis of Fear Appeal Effectiveness and Theories. Psychology Bulletin 141, no. 6 (2015): 1176-1204. https://doi.org/10.1037/a0039729

Taylor, Barry. W. Diversion of Church Funds to Personal Use: State, Federal and Private Sanctions. Journal of Criminal Law and Criminology 73, no. 3 (1982): 1204-1237.

The Holy Bible: English Standard Version (ESV).

The Holy Bible: New American Standard Bible (NASB).

The Holy Bible: New International Version (NIV).

The Holy Bible: New Living Translation (NLT). 